\title{
NAUCZANIE HYBRYDOWE W NAUCE JĘZYKÓW OBCYCH
}

\author{
KRZYSZTOF BAŁABAN \\ Uniwersytet Wrocławski \\ krzysztof.balaban@uwr.edu.pl \\ ORCID: 0000-0002-7692-0415
}

\section{STRESZCZENIE}

W artykule omówiono znaczenie hybrydowego podejścia do nauczania języków obcych. Artykuł ten zawiera podstawowe definicje i podejmuje próbę wyjaśnienia korzyści wynikających $\mathrm{z}$ tej metody. W treści wykazano jak ważne jest wykorzystanie nowoczesnych technologii $\mathrm{w}$ nauczaniu języka obcego.

SŁOWA KLUCZOWE: nauczanie hybrydowe, blended learning, e-learning, języki obce

\section{HYBRID TEACHING IN FOREIGN LANGUAGE LEARNING}

\section{ABSTRACT}

The article discusses the importance of the hybrid approach to teaching foreign languages. This article contains basic definitions and attempts to explain the benefits of this method. The content shows how important is the use of modern technologies in teaching a foreign language.

KEYWORDS: hybrid teaching, blended learning, e-learning, foreign languages.

\section{WPROWADZENIE}

Głównym celem pracy jest przedstawienie korzyści płynących $\mathrm{z}$ zastosowania hybrydowego podejścia do nauczania języków obcych.

W pierwszej części artykułu wyjaśniono jak należy rozumieć pojęcia nauczania hybrydowego (ang. hybrid learning) i metody mieszanej (ang. blended learning, b-learning). Jest to istotne, ponieważ terminy te są często niepoprawnie stosowane. $\mathrm{W}$ dalszej kolejności przedstawiono zalety i wady metody nauczania hybrydowego $\mathrm{w}$ porównaniu $\mathrm{z}$ metodą mieszana nauczaniem bezpośrednim i zdalnym. Skupiono się na prezentacji znaczenia tych metod w przypadku nauczania języków obcych.

Stale rozwijające się technologie informatyczne i komunikacyjne obejmują wszelkie sfery ludzkiej działalności. Również w nauczaniu znajdują one coraz szersze zastosowanie. W dzisiejszych czasach nauczyciel powinien umiejętnie posługiwać się zasobami technologii informacyjnej zarówno w procesie kształcenia uczniów, jak i wykonywaniu innych zadań związanych z pracą dydaktyczną. Obecnie na rynku znaleźć można wiele ciekawych środków 
dydaktycznych w postaci programów multimedialnych, gier komputerowych, filmów i nagrań dźwiękowych. Coraz więcej pojawia się też edukacyjnie wartościowych stron internetowych. Ważnym zadaniem nauczyciela jest umiejętność oceny dostępnych materiałów pod względem merytorycznym, a także znalezienie dla nich odpowiedniego miejsca w procesie kształcenia.

\section{NAUCZANIE HYBRYDOWE VS. METODA MIESZANA}

Nauczanie hybrydowe nie doczekało się jeszcze swojej uniwersalnej definicji. W literaturze naukowej wobec tej metody można spotkać się z zamiennym używaniem takich terminów jak:

- nauczanie mieszane;

- nauczanie hybrydowe;

- model mieszany.

Nauczanie hybrydowe bywa najczęściej definiowane jako wypadkowa dwóch typów nauczania - tradycyjnego i prowadzonego w formie e-learning'u. Nie są to jednak synonimy. Rebecca Böttcher (Böttcher 2013: 93) dobrze odróżnia te terminy:

Mieszana metoda kształcenia to rozwiązanie polegające na tym, że uczniowie korzystają z zajęć online i w klasie. Etapy nauczania w obu środowiskach współgrają ze sobą jednak ich stosunek procentowy może się różnić w zależności od typu stosowanych mediów.

W przypadku nauczania hybrydowego najważniejsza część zajęć odbywa się w klasie, jednak media cyfrowe są stosowane podczas tradycyjnych lekcji oraz jako ich uzupełnienie.

Powyższe metody łączy wykorzystanie wielu różnych mediów w procesie nauczania. Scalają one klasyczne metody nauczania stacjonarnego $\mathrm{z}$ innowacyjnymi sposobami wykorzystywanymi w nauczaniu zdalnym. To znacząco wpływa na wzbogacenie procesu edukacyjnego. Takie metody nauczania stanowią odpowiedź na społeczną potrzebę ciągłego i nieograniczonego dostępu do informacji i konieczność kształcenia się przez całe życie.

Mieszana metoda kształcenia jest to zatem forma uczenia się, łącząca w sobie zajęcia tradycyjne $\mathrm{z}$ aktywnościami prowadzonymi zdalnie przy pomocy komputera. W praktyce oznacza to, że w porównaniu do tradycyjnego modelu, uczestnicy biorący udział w takim kursie spotykają się najczęściej sporadycznie w celu weryfikacji wiedzy, przyswajanej zdalnie.

Schemat przeprowadzania zajęć w tym systemie polega na przeplataniu się zajęć stacjonarnych ze zdalnymi. Najczęściej przebiega on w oparciu o zastosowanie jednego z dwóch wariantów (por. Nowak 2012):

Wariant pierwszy - na początkowym etapie szkolenia studentom zostają udostępnione materiały dydaktyczne w postaci multimedialnej. Daje im to możliwość bliższego zapoznania się z tematem szkolenia, poznania nowych 
zagadnień, a także wyrównania różnic w poziomie wiedzy pomiędzy kursantami. Czas na zajęcia z lektorem poświęcony jest z kolei na omówienie kwestii problematycznych i wymianę doświadczeń. Powtórne szkolenie elearningowe daje możliwość utrwalenia zdobytej wiedzy oraz sprawdzenia osiągnięć m.in. poprzez przeprowadzenie testów online.

Wariant drugi jest wersją cykliczna, mogącą przebiegać w procesie długofalowym. Szkolenie e-learningowe funkcjonuje tu na zasadzie utrwalania wiedzy oraz jej sprawdzania po przerobieniu pewnej partii materiału z lektorem. Przekaz tradycyjny w tym przypadku jest wzbogacany o takie elementy kształcenia jak np. dyskusja czy kształtowanie umiejętności interpersonalnych.

Celem mieszanej metody nauczania jest zatem połączenie dwóch aspektów uczenia się: bezpośredniego z nauczycielem oraz poprzez instrukcje online (elearning). Czas spędzony z nauczycielem jest wykorzystywany m.in. w celu omówienia kwestii problematycznych i wymiany doświadczeń. Istotne jest tutaj to, że studenci mogą korzystać z przygotowanych dla nich materiałów w dowolnym miejscu i o dogodnej porze dnia. Daje to kursantom dużą elastyczność potrzebną w natłoku innych zajęć.

Warto zauważyć, że nie ma jedynych prawidłowych proporcji, jeśli chodzi o udział w procesie nauczania metody bezpośredniej i zdalnej. Stosunek poszczególnych elementów powinien być dobierany w zależności od treści kursu i potrzeb studentów.

\section{NAUCZANIE HYBRYDOWE VS. NAUCZANIE BEZPOŚREDNIE}

Podejmując się porównania nauczania bezpośredniego $\mathrm{z}$ hybrydowym $\mathrm{w}$ przypadku nauki języków obcych należy zacząć od tego, że warunkiem przygotowania dobrego kursu języka obcego jest sporządzenie spójnego i metodologicznie poprawnego programu nauczania. Ważnym elementem jest dobór odpowiedniego zespołu dydaktycznego. Powinien on być kreatywny i odpowiednio zmotywowany. Stanowi to duże ułatwienie $w$ tworzeniu środowiska nauczania hybrydowego i wprowadzaniu różnych narzędzi cyfrowych do codziennej pracy nauczyciela. Jest to istotne, ponieważ przygotowanie wysokiej jakości materiałów dydaktycznych w postaci multimedialnej może stanowić prawdziwe wyzwanie. Przede wszystkim należy zebrać materiały, które powinny być w formie multimedialnej. Jest to proces czasochłonny i wymagający dużego nakładu pracy.

Osoby przygotowujące zajęcia powinny brać pod uwagę poniższe elementy:

- charakterystyczne cechy i możliwości danego modelu przekazywania wiedzy;

- indywidualne cechy osobowości uczących się;

- możliwości percepcyjne uczących się;

- umiejętność skupienia się na danym typie przekazu;

- inne - jak np. umiejętność przygotowania materiałów w formie multimedialnej. 
Zalety nauczania bezpośredniego:

- możliwość bezpośredniego kontaktu z nauczycielem, co zapewnia szybką interakcję i rozwiązanie wątpliwości;

- utrzymywanie bezpośrednich relacji interpersonalnych;

- wiarygodna weryfikacja pozyskanej wiedzy poprzez tradycyjnie przygotowany egzamin, inaczej niż w przypadku testu przeprowadzonego, gdzie zdalnie brak jest możliwości sprawdzenia, kto i w jaki sposób odpowiada na stawiane pytania sprawdzające.

Wady nauczania bezpośredniego:

- wysoki koszt nauczania, wynikający m.in. z kosztów poniesionych na wynajęcie sal dydaktycznych;

- zunifikowany program szkolenia - z uwagi na różny poziom początkowej wiedzy i umiejętności uczących się (często w fazie początkowej program nauczania dostosowywany jest do osoby o najniższym poziomie wiedzy);

- czasochłonność procesu szkolenia - każda grupa uczących się wymaga rezerwacji odpowiednich zasobów szkoleniowych, w tym pracy nauczyciela;

- werbalny przekaz wiedzy wspierany zwykle materiałami pomocniczymi w formie papierowej. Chociaż znacząco wygodniejszą formą budowy pomocniczych zasobów wiedzy jest postać elektroniczna.

Nauczanie bezpośrednie $\mathrm{z}$ nauczaniem hybrydowym łączy przede wszystkim to, że oba zapewniają bezpośredni kontakt z prowadzącym, co stanowi ważną cechę tych zajęć. Relacje międzyludzkie stanowią istotny element efektywnego uczenia się: efektywność nauczania zależy od dobrego przepływu informacji, możliwości wspólnego uczestniczenia w zajęciach. To w efekcie wzmacnia wzajemne relacje międzyludzkie.

\section{NAUCZANIE HYBRYDOWE VS. NAUCZANIE ZDALNE}

Zalety nauczania zdalnego:

- ciągłość pracy osób uczących się;

- zindywidualizowany i sterowany proces pozyskiwania wiedzy; możliwość pomijania znanych zagadnień lub dokonywanie dowolnej ilości powtórzeń przy trudniejszych do opanowania;

- redukcja kosztów uczenia się i nauczania, związanych z wydatkami na infrastrukturę szkoleniową (sale i urządzenia do prezentacji).

Wady nauczania zdalnego:

- brak w pełni wiarygodnych możliwości zweryfikowania wyników nauczania oraz aktualnie pozyskiwanej wiedzy;

- wysokie koszty budowy i organizacji procesu nauczania, generowane poprzez konieczność budowania odpowiedniego środowiska do uczenia się (jego zaprojektowanie wymaga czasu i odpowiednich nakładów finansowych);

- brak bezpośredniego kontaktu uczących się pomiędzy sobą oraz nauczycielem; 
- możliwy zanik motywacji do uczenia się i pełnego zaangażowania studenta.

Nauczanie hybrydowe łączy w sobie przedstawione wcześniej zalety nauczania bezpośredniego i zdalnego, ograniczając jednocześnie ich niedogodności.

A zatem najważniejsze zalety nauczania hybrydowego to:

- zapewniony bezpośredni kontakt z nauczycielem; zawsze można liczyć na szybkie wyjaśnienie problemów podczas zajęć;

- możliwość nawiązania nowych kontaktów i znajomości;

- wiarygodność weryfikacji pozyskanej wiedzy; odbywa się ona pod nadzorem nauczyciela w formie egzaminu, co ma istotny wpływ na motywację do pozyskania wiedzy na odpowiednio wysokim poziomie;

- posiadanie przez osoby uczące się materiałów pozwalających na indywidualne podejście do procesu pozyskiwania wiedzy.

Jeśli posiadana wiedza wykracza poza przyjęty standard, można na uczenie się poświęcić mniej czasu. Natomiast jeśli jest ona mniej zaawansowana można zapoznać się z wybranymi materiałami dydaktycznymi udostępnionymi w Internecie nawet kilkakrotnie, aż uzna się problem za opanowany na tyle, że następujący w dalszej kolejności nauki udział w zajęciach będzie efektywny.

\section{PODSUMOWANIE}

Porównanie wad i zalet metod nauczania hybrydowego, mieszanego, bezpośredniego i zdalnego wydaje się przekonywać do pierwszego z nich. Z tego względu warto zastanowić się nad przebudową funkcjonującego obecnie najszerzej w szkolnictwie bezpośredniego modelu budowania wiedzy i kompetencji, ponieważ nauczanie hybrydowe daje możliwość efektywnych ekonomicznie i metodycznie form realizacji założonych celów nauczania.

Reasumując - koncepcja nauczania hybrydowego jest dobrym rozwiązaniem. Metoda ta opiera się na wykorzystywaniu materiałów dostępnych online jedynie jako czynnika wspierającego proces dydaktyczny, bez rezygnacji z regularnych spotkań z prowadzącym zajęcia. Warto podkreślić, że nauczyciele języków obcych, szczególnie młodzi, są zainteresowani podnoszeniem swoich kwalifikacji zawodowych poprzez zdobywanie wiedzy i praktycznych umiejętności w zakresie wykorzystywania nowych technologii informacyjnych i multimedialnych w nauczaniu języka obcego. Mając na uwadze własne spostrzeżenia i obserwacje, uważają je za dobre narzędzia wspierające nauczanie. Należy podkreślić, że szczególnym zadaniem nauczyciela języków obcych jest dostosowanie wykorzystywanych podczas zajęć multimediów do możliwości rozwojowych uczniów i zachowanie odpowiednich proporcji czasowych w organizowanych zajęciach w stosunku do prowadzonych $\mathrm{z}$ wykorzystaniem komputera. 


\section{BIBLIOGRAFIA}

BÖTTCHER, R. (2013), Nauczanie hybrydowe - przyszłość nauki języków obcych, Języki Obce w Szkole, 2, 92-97.

GŁOWICKI, P. (2009), Nauczanie hybrydowe - koncepcja i rozwiązania, Pomiary. Automatyka. Kontrola, 7, 531-533.

NowAK, R. (2012), Blended learning - przyszłość polskiej edukacji [w:] www.edulider.pl, http://www.edulider.pl/edukacja/blended-learning-przyszlosc-polskiej-edukacji

OLEJARCZUK, E. (2016), Projektowanie kursu blended learning - komponent elearningowy, Jezzyki Obce w Szkole, 3, 43-46. 